\title{
Cytogenetic homeostasis and population density in red-backed voles Clethrionomys glareolus and C. rutilus in central Siberia
}

\author{
Sergey G. DMITRIEV, Vladimir M. ZAKHAROV and Boris I. SHEFTEL
}

\begin{abstract}
Dmitriev S. G., Zakharov V. M. and Sheftel B. I. 1997. Cytogenetic homeostasis and population density in red-backed voles Clethrionomys glareolus and C. rutilus in central Siberia. [In: Developmental homeostasis in natural populations of mammals: phenetic approach. V. M. Zakharov and A. V. Yablokov, eds]. Acta Theriologica, Suppl. 4: $49-55$.

We examined frequency of chromosome aberration in somatic cells in sympatric growing populations of bank vole Clethrionomys glareolus Schreber, 1780 and ruddy vole $C$. rutilus Pallas, 1779 in central Siberia (Yenisei river island, $62^{\circ} \mathrm{N}, 89^{\circ} \mathrm{E}$ ) from 1992 to 1994 . The island was reinhabited from the mainland populations in 1992 after abnormally high flooding which eliminated the previous island populations of the species. The frequency of chromosome aberration increased parallel to the population density of island populations of both species in 1992-1994. In the mainland population of $C$. rutilus in 1994, the year of low density for this highly cyclic population, significantly lower frequency of chromosome aberration was found as compared with an island population characterized by high density in this year. These results are interpreted as a disturbance of cytogenetic homeostasis indicating an alteration in an organism's condition in the overcrowded populations of both species under study.

N. K. Koltzov Institute of Developmental Biology, Russian Academy of Science, Vavilov Str. 26, Moscow 117808, Russia (SGD, VMZ); Institute of Evolutionary and Ecological Problems, Russian Academy of Science, Leninsky prospekt 33, Moscow 117071, Russia (BIS)
\end{abstract}

Key words: Clethrionomys glareolus, C. rutilus, chromosome aberrations, cytogenetic homeostasis, population dynamics

\section{Introduction}

Overpopulation is one of the natural stresses. It is considered as an important factor for population density regulation (Christian 1950, 1971, 1978, Jewell 1966, Koshkina and Korotkov 1975, Shilov 1977, Chernyavski and Tkachev 1982). To establish a population density as a factor adversely affected an organism's condition, it is crucial to demonstrate that such changes could be revealed by important parameters of an organism's homeostasis (Broom and Johnson 1993). Cytogenetic homeostasis, as an organism's ability to provide the kariotype stability, characterizing mutagenic activity and an immune ability of an organism is one of such parameters (Kerkis 1977, Ilyinskikh et al. 1986, Krysanov and 
Dmitriev 1993, Zakharov 1994). Adverse effect of various toxic impact on cytogenetic homeostasis have been registered in numerous studies: chromosome aberration study is one of the common measure in toxicological research (Dean and Danford 1984, McBee et al. 1987, Tice et al, 1987, Wolf 1991, Gileva et al. 1992, McBee 1994).

The aim of the study is to reveal possible changes in cytogenetic homerstasis in natural populations of small mammals. Temporal variation in cytogenetic homeostasis was measured by frequency of chromosome aberrations in somatic cells in sympatric island populations of two red-backed vole species: bank vole Clethrionomys glareolus Schreber, 1780 and ruddy vole C. rutilus Pallas, 1779, as a function of population density. Our hypothesis is that adverse effect of high population density on physiological condition of voles could be registered by increased level of chromosome aberrations.

\section{Material and methods}

Sympatric populations of voles from central Siberia (the bank of the Yenisei river, the Northern Ecological Station of the Institute of Evolutionary and Ecological Problems, Russian Academy of Sciences, $62^{\circ} \mathrm{N}, 89^{\circ} \mathrm{E}$ ) were studied. The main material was collected in 1992-1994 from an island of $0.5 \mathrm{~km}^{2}$ isolated from the bank of the Yenisei river by water obstacle of the width oscillated from 30 to $800 \mathrm{~m}$ and sand dunes $800 \mathrm{~m}$ of width. The voles populations were growing in number in the island from 1992 to 1994 . Small mammals populations on an island were eliminated by abnormaly high flooding in spring in 1992. The island was recolonized from permanently existing mainland populations. Additionally, the ruddy vole sample was collected from the inland population in 1994, the year of low density for this highly cyclic population (Fig. 1). Voles were collected by live traps in July. Population density was estimated by catch index calculated as number of individuals caught per 100 traps per night.

Population density estimates revealed essential difference between the species: population density of the bank vole was much lower than it was for the ruddy vole during the whole studying period (Fig. 2). Thus, during the whole trapping period in 1992, a year of recolonization of an island, we

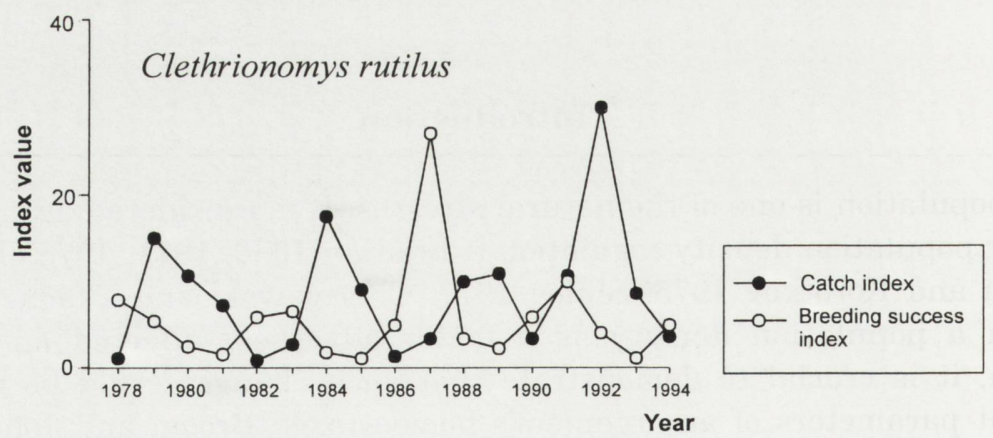

Fig. 1. Population dynamics (catch index - a number of specimens caught by 100 traps per night) and breeding success index of the ruddy vole Clethrionomys rutilus on the bank of the Yenisei river, central Siberia. 
collected only one bank vole. Population dynamics on the mainland and on the island proved to be independent (Fig. 2). A long term population study in the locality revealed a high regular 4-year cycle for small mammals, including ruddy vole that proved to be synchronous on the both banks of the Yenisei river (Sheftel 1983, 1989). Breeding success, calculated by dividing the number of immature

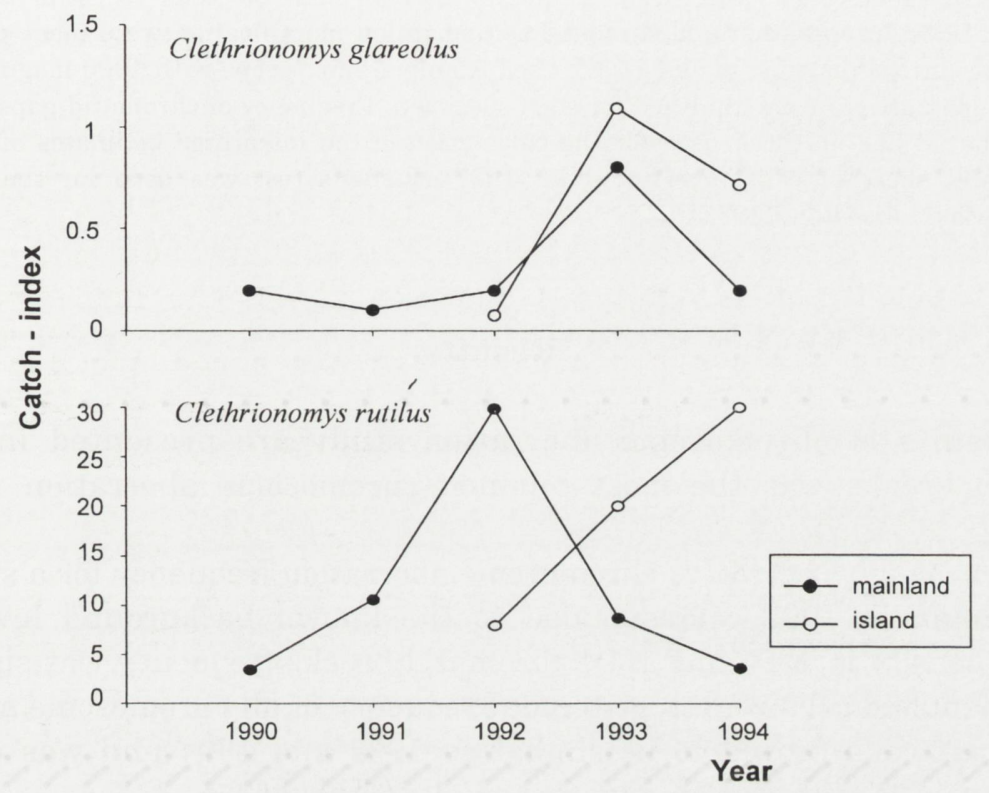

Fig. 2. Population dynamics (catch index - a number of specimens caught by 100 traps per night) in the mainland and on the island populations of two red-backed vole species.

Table 1. Frequency (\%) of chromosome aberrations and aberrant cells in different samples of two vole species. The numbers of chromosome aberrations and aberrant cells are presented in brackets.

\begin{tabular}{|c|c|c|c|c|c|c|c|}
\hline & \multicolumn{3}{|c|}{ Clethrionomys glareolus } & \multicolumn{4}{|c|}{ Clethrionomys rutilus } \\
\hline & $\begin{array}{c}\text { island } \\
1992\end{array}$ & $\begin{array}{c}\text { island } \\
1993\end{array}$ & $\begin{array}{c}\text { island } \\
1994\end{array}$ & $\begin{array}{c}\text { island } \\
1992\end{array}$ & $\begin{array}{c}\text { island } \\
1993\end{array}$ & $\begin{array}{c}\text { island } \\
1994\end{array}$ & $\begin{array}{c}\text { mainland } \\
1994\end{array}$ \\
\hline$n=$ & $\begin{array}{c}1 \\
(50 \text { cells })\end{array}$ & $\begin{array}{c}10 \\
(250 \text { cells })\end{array}$ & $\begin{array}{c}6 \\
\text { (291 cells) }\end{array}$ & $\begin{array}{c}13 \\
\text { (572 cells) }\end{array}$ & $\begin{array}{c}13 \\
(350 \text { cells })\end{array}$ & $\begin{array}{c}12 \\
(590 \text { cells })\end{array}$ & $\begin{array}{c}6 \\
(300 \text { cells })\end{array}$ \\
\hline Chromatid gaps & - & 1.60 & - & $1.39(8)$ & $2.57 \quad(9)$ & $1.18 \quad(7)$ & $1.00 \quad(3)$ \\
\hline Chromatid breaks & $2.00(1)$ & $7.20(18)$ & $7.56(22)$ & $2.97(17)$ & $6.85(24)$ & $11.3(67)$ & $2.30 \quad(7)$ \\
\hline Chromosome breaks & - & - & - & $0.34 \quad(2)$ & - & - & - \\
\hline Aneuploidcells & - & 0.39 & $0.68 \quad(2)$ & - & - & $0.84 \quad(5)$ & 1.00 \\
\hline Inversions & - & - & - & - & - & 0.17 & - \\
\hline All lesions & $2.00(1)$ & $7.20(18)$ & $7.56(22)$ & $3.32(19)$ & $6.85(24)$ & $11.3(67)$ & $2.30 \quad(7)$ \\
\hline Aberrant cells & $2.00(1)$ & $7.60(19)$ & $7.90(23)$ & $3.32(19)$ & $6.28(22)$ & $7.1(42)$ & $3.33(10)$ \\
\hline
\end{tabular}


voles by the number of breeding adult voles, had a tendency for a negative correlation $\left(r_{\mathrm{S}}=-0.45\right.$, $p<0.05$ ) with density (Fig. 1).

Only young specimens born in the studied year were analyzed (Table 1). The samples consisted of individuals of both sexes were used as we did not reveal significant difference (Fisher's test) between males and females in studied parameters.

We studied chromosome aberration frequency in bone marrow cells to estimate cytogenetic homeostasis. Slides preparation and chromosome aberration identification were made according the standard procedure (Preston et al. 1987). We used Amplival microscope with 1000 magnification. Not less than 25 metaphases were analyzed for each specimen. Frequency of chromatid gaps is presented in Table 1, but it has not been used for the calculation of the integrated estimates of chromosome aberration and aberrant cells (Preston et al. 1987). Fisher's test was used for the intersample comparison (Sokal and Rohlf 1981).

\section{Results}

The results of chromosome aberration study are presented in Table 1 . Chromatid breaks was the most common chromosome aberration in studied material.

In Clethrionomys glareolus chromosome aberration frequency for a single bank vole specimen in 1992 corresponded to the known background level. Under increased density in 1993 and 1994 chromatid breaks frequency was significantly higher. Aneuploid cells were registered. Frequency of all chromosome aberrations and aberrant cells proved to be similar in 1993 and 1994 and was essentially higher $(p<0.01)$ than known spontaneous level, about $3 \%$.

In Clethrionomys rutilus chromatid breaks frequency, as the most common type of chromosome aberration, increased in a set of annual samples of ruddy vole collected on the island from 1992 to 1994 (Table 1). Mainland sample of the species in 1994 showed a lowest frequency close to that of the island sample in 1992. These frequencies were significantly lower $(p<0.01)$ than frequencies of the samples collected from the island in 1993 and 1994. Serious chromosome disturbances were revealed in two individuals collected on island in 1994. Up to 10 breaks per cell and 58\% of aberrant chromosome per individual were observed for these individuals. But even without these two individuals the frequency of aberrant cells was still twice higher in this sample than in a sample collected from the island in a year of low density (1992). Island samples of 1993 and 1994 were different only in a number of aberrant chromosome. The frequency of aberrant cells proved to be similar in these samples. It was also similar for two other samples collected from the island in 1992 and from the mainland in 1994. Other types of chromosome disturbances, gaps and aneuploidy, were registered irregularly and did not show such a gradient as it was for the chromatid breaks. The changes in a chromosome aberration frequency prove to be similar to the changes in a population density (Table 1 and Fig. 2). 


\section{Discussion}

An increase in chromosome aberration frequency is commonly used as an indication of essential changes in an organism's condition (Kerkis 1977, Ilyinskikh et al. 1986, Brusick 1987, Wolf 1991, McBee 1994). Deterioration of developmental homeostasis has been already registered under high density in shrew populations by morphogenetic measures (Zakharov et al. 1991, 1997). To reveal changes in cytogenetic homeostasis seems to be important for many reasons: (i) to monitor changes in cytogenetic homeostasis in natural conditions, (ii) to support an idea that overpopulation could adversely affect an organism condition that would lead to a density decline, (iii) to establish developmental homeostasis study in natural population as an important approach to assess an organism's condition.

It has been established that hormone changes under the stress impact could affect mutagenic, recombinant and reparation activities (Kerkis and Skorova 1977, Borodin and Beliaev 1980, Vasiliev 1982, Gorlov and Borodin 1986). Changes in an immune status and cytogenetic homeostasis have been observed in the laboratory studies of the social stress impact in rats (Bykovskaya et al. 1994, Pronin et al. 1997).

The data of this study reveal a cytogenetic homeostasis disturbance under the density increase in both species under study. The frequency of chromosome aberrations is minimal under the low density in both island and mainland populations, while it proves to be higher under the high density. Adverse effect of a density increase, registered already in the second year after recolonization of an island, is most probably caused by small size of this isolated area. The density that adversely effects an organism's condition of the ruddy vole on the island is rather high and proves to be similar to the level registered in a peak year in a cyclic mainland population (Figs 1 and 2). The deterioration of an organism's condition in the bank vole is observed at essentially lower density. The studying locality is a periphery of the species range for the bank vole occurring here only in the water-meadow of Yenisei river and its density is always much lower than it is for the ruddy vole (Shvarts et al. 1987). The fact that we observe synchronous changes in an organism's condition for both the abundant and the rare species supports the hypothesis that overpopulation stress impact can be caused by increased density of different species (Zakharov et al. 1991). The data illustrate that changes in cytogenetic homeostasis indicating an alteration in an organism's condition could occur under the stress impact in natural conditions and evidence a perspectiveness to monitor such changes for the species with different type of population dynamics.

Acknowledgements: We acknowledge a help of Mr D. V. Demin and Mrs O. L. Zeldich in the trapping of voles. We are very grateful to Dr J. H. Graham and two anonymous referees provided very helpful comments and corrections of English. 


\section{References}

Borodin P. M. and Belyaev D. K. 1980. [Effect of stress of the crossingover in 2nd chromosome of laboratory mouse.] Doklady Akademii Nauk 3: 727-729. [In Russian]

Broom D. M. and Johnson K. G. 1993. Stress and animal welfare. Chapman and Hall, London: 1-211. Brusick D. 1987. Principles of genetic toxicology. Plenum Press, New York: 1-284.

Bykovskaya N. V., Dyuzhikova N. A., Vaido A. I., Lopatina N. G. and Shvartsman P. Ya. 1994. Frequency of chromosomal aberrations induced by stress and cyclophosphamide in bone marrow cells of rats selected for the threshold of nervous system excitability. Genetika 30: 1224-1228. [In Russian with English summary]

Chernyavski F. B. and Tkachev A. V. 1982. [Population cycles of lemmings in Arctic: ecological and endocrine aspects.] Nauka, Moskva: 1-160. [In Russian]

Christian J. J. 1950. The adreno-pituitary system and population cycles in mammals. Journal of Mammalogy 31: 247-259.

Christian J. J. 1971. Population density and reproductive efficiency. Biological Reproduction 4: $248-294$.

Christian J. J. 1978. Neurobehavioural endocrine regulation of small mammal populations [In: Populations of small mammals under natural conditions. D. P. Snyder, ed]. Pymatuning Laboratory of Ecology, Special Publication 5: 143-158.

Dean B. J. and Danford N. 1984. Assays for detection of chemically induced chromosome damage in cultured mammalian cells. [In: Mutagenicity testing, a practical approach. S. Venitt and J. M. Parry, eds]. IRL Press, Oxford: 187-232.

Gileva I. A., Bolshakov V. N., Kosareva N. L. and Gabitova A. T. 1992. [Frequency of the chromosomal aberration in the commensal house mice as an indicator of genotoxic effects of the environmental pollution.] Doklady Akademii Nauk 5: 1058-1061. [In Russian]

Gorlov I. P. and Borodin P. M. 1986. The effects of the emotional stress on the frequency of meiotic disturbances in male mice. Genetika 6: 1019-1024. [In Russian with English summary]

Ilyinskikh N. N., Ilyinskikh I. N. and Bocharov E. F. 1986. [Cytogenetic homeostasis and immunity.] Nauka, Novosibirsk: 1-256. [In Russian]

Jewell P. A. 1966. Breeding season and regulations in some British mammals confined on small island. Symposium of Zoological Society of London 15: 89-116.

Kerkis Yu. Ya. 1977. [Some aspects of studying of the human environment.] [In: Genetic consequences of the pollution of the environment. N. P. Dubinin, ed]. Nauka, Moskva: 37-41. [In Russian]

Kerkis Yu. Ya. and Skorova S. V. 1977. [About factors, controlling the intensity of the spontaneous mutation process.] Informatsionnyi Byulleten Nauchnogo Soveta po Problemam Meditsiny 20: 51-52. [In Russian]

Koshkina T. V. and Korotkov Yu. S. 1975. [Regulatory adaptations in the population of ruddy vole in the optimum of species range.] Fauna i Ekologya Gryzunov 12: 5-62. [In Russian]

Krysanov E. Y. and Dmitriev S. G. 1993. Genetic approach. [In: Biotest: a new integrated biological approach for assessing the condition of natural environments. V. M. Zakharov and G. M. Clarke, eds]. Moscow Affiliate of the International Biotest Foundation, Moscow: 41-45.

McBee K. 1994. Adaptation of mutagenicity and clastogenecity assays for avian species. [In: Wildlife toxicology and population modeling. Integrated studies of agroecosystems. Proceedings of the 9th Pellston workshop, Kiawah island, South Carolina, July 22-27, 1990. R. J. Kendall and T. E. Lacher, eds]. CRC Press. Boca Raton, Florida: 383-400.

McBee K., Bickham J. M., Brown K. W. and Donelly K. C. 1987. Chromosomal aberrations in native small mammals (Peromyscus leucopus and Sigmodon hispidus) at petrochemical waste disposal site: 1. Standard karyology. Archives of Environmental Contamination Toxicology 16: 681-688.

Preston J. R., Dean B. J., Galloway S., Holden H., McFee A. F. and Shelby M. 1987. Mammalian in vivo cytogenetic assays. Analysis of chromosome aberrations in bone marrow cells. Mutation Research 189: 157-165. 
Pronin A. V., Nikolaeva T. N., Deyeva A. V., Zaytseva L. G., Vasil'eva E. I., Kirillicheva G. B., Baturina I. G., Solov'eva M. S. and Zakharov V. M. 1997. Social stress in laboratory rats Rattus norvegicus results in decreased immune competence of the offspring. [In: Developmental homeostasis in natural populations of mammals: phenetic approach. V. M. Zakharov and A. V. Yablokov, eds]. Acta Theriologica, Suppl. 4: 33-40.

Sheftel B. I. 1983. [Zonality of populations of shrews in Yenisei taiga.] [In: Animals and natural zonality of Yenisei taiga and forest tundra. E. E. Siroechkovsky, ed]. Nauka, Moskva: 184-203. [In Russian]

Sheftel B. I. 1989. Long-term and seasonal dynamics of shrews in Central Siberia. Annales Zoologici Fennici 26: 357-370.

Shilov I. A. 1977. [Ecologo-physiological foundations of population relations in animals.] Moscow University Press, Moskva: 1-261. [In Russian]

Shvarts E. A., Sheftel B. I. and Zhukov M. A. 1987. [Eastern part of the species range of the red-backed vole.] Bulleten Moskovskogo Obshestva Ispytatelei Prirody 92 (2): 17-26. [In Russian]

Sokal R. R. and Rohlf J. F. 1981. Biometry. Freeman, San Francisco: 1-859.

Tice R. R., Ormiston B. G., Boucher C. A., Luke C. A. and Paquette D. E. 1987. Environmental biomonitoring with feral rodent species. [In: Short-term bioassays in the analysis of complex environmental mixtures. S. S. Sandhu, D. M. Demarine, M. J. Mass, M. M. More and J. M. Mamford, eds]. Plenum Press, New York: 175-179.

Vasilyev V. I. 1982. Effect of cortisol on the repair synthesis and methylation of rat liver DNA. Bulleten Eksperimentalnoi Biologii i Meditsiny 11: 39-41. [In Russian with English summary]

Wolf S. 1991. Biological dosimetry with cytogenetic endpoints. [In: New horizons in biological dosimetry. Progress in clinical and biological research. B. L. Gledhill and F. Mauro, eds]. Wiley-Liss Inc., New York 372: 351-362.

Zakharov V. M. 1994. Population-phenogenetic approach for ecological monitoring (a Biotest). [In: Wildlife toxicology and population modeling. Integrated studies of agroecosystems. R. J. Kendall and T. E. Lacher, eds]. CRC Press, Boca Raton, Florida: 99-107.

Zakharov V. M., Pankakoski E. and Sheftel B. I. 1997. Phenotypic diversity and population dynamics: another look (with particular reference to the common shrew Sorex araneus). [In: Developmental homeostasis in natural populations of mammals: phenetic approach. V. M. Zakharov and A. V. Yablokov, eds]. Acta Theriologica, Suppl. 4: 57-66.

Zakharov V. M., Pankakoski E., Sheftel B. I., Peltonen A. and Hanski I. 1991. Developmental stability and population dynamics in the common shrew, Sorex araneus. American Naturalist 138: 797-810.

Received 11 October 1995, revised 10 October 1996, accepted 10 June 1997. 